Parés

\title{
Comedies with corpses but without weeping or mourning
}

The article questions the problematic figuration of the corpse in the history of Spanish cinema and particularly in the genre of comedy. Starting with a verification of the centrality of death and its representations in Spanish culture, the author inquires into the ways in which corpses are present in our cinema and how the approach to this motif explains a particular attitude in terms of history and encodes a critical eye or an escapist attitude on the part of filmmakers and films. After tracing a genealogy of its representations, taking the bodies of the fallen in the Spanish Civil War as the first important corpses, the text creates a symptomatic history of the different forms of corpse representation in Spanish post-war cinema, focusing on the way in which the figure is shifted towards the field of comedy and its evolution, going from an evasive, depoliticized approach towards the territory of darkness and critical penetration. The author also points to the relevance of corpse representation in the cinema of the Transition, and its disappearance when democracy was consolidated. Finally, the representation of the corpse is established as a significant tool for confirming the critical load of Spanish cinema in relation to its history and its present.

Keywords

CORPSE

SPANISH CINEMA

HISTORY

CINEMA HISTORY

COMEDY

SPANISH CULTURE

DEATH

BLACK COMEDY

TRANSITION

Date of reception: 16/07/2018

Date of acceptance: 20/06/2019

Luis E. Parés (Madrid, 1982) Historian and documentalist. He has published the books Notes sur l'emigration-Espagne 1960. Apunts per a una pel-lícula invisible and Filmar el exilio desde Francia. As a producer, he has worked at different festivals and institutions, such as Zinebi, Punto de Vista, the Seville International Film Festival and Filmoteca Española, and has coordinated the daily RTVE program Historia de nuestro cine. His work has focused on Spanish cinema, particularly the "second exile" and the construction of a new cultural narrative based on the recovery of the images ignored by traditional historiography. 
"Spaniards suffer from a disadvantage: they

are not particularly gifted when it comes to cinematographic mise-en-scène. A handicap for which they largely compensate by the richness of their pictorial expression."

Luc Moullet

In Spanish culture, death has always been a constant presence. However, Spanish culture has always used it as a symbol for moral reflection. From Jorge Manrique's coplas to Quevedo's verse "ash they will be, but filled with meaning"1, from the vanities of Valdés Leal to the sculptures of Gaspar Becerra, Spanish culture, gifted with great iconic power, has never ceased to reflect on the fleeting nature of glory, the inconsistency of emotions and even the absurdity of earthly ties. And in this game of moral representation, the corpse has been one of the most persistent metaphors.

What impressed Gautier and Manet on their visits to the Prado Museum in the 19th century was the union between the carnality of representation and the moral symbology of the images. In a letter to Baudelaire, Manet defined Spanish art as beautiful and dreadful. However, that beautiful and dreadful iconicity of Spanish painting, which didn't shy away from painting a corpse, did not continue on into Spanish cinema, the proponents of which have instead sought to affiliate themselves with popular theater (the sainete or astracanada $^{2}$ ) rather than with the pictorial school. This might be the reason for the problems that Spanish cinema has had when portraying corpses.

It is hard to know which the first corpse to appear in Spanish cinema was, due to the scarcity of filmic material that has survived (it is estimated that $94 \%$ of the films created in Spain before the Spanish Civil War has been lost). In silent film there are famous corpses, like the one in Asesinato y entierro de don José Canalejas ("Murder and Burial of Mr. José Canalejas", 1912), a short film made by Enrique Blanco and Adelardo Fernández Arias that recreated the attack on José Canalejas in order to spread the news about his death. It is interesting to note that the role of the murderer is played by José Isbert, who is forever linked in our viewers' minds with the profession of executioner.

The next important link in this chain might be the corpse of the baby in Buñuel's Land Without Bread (Las Hurdes, 1933), a corpse that is transported across the water in a wooden box. This corpse, which later investigations seem to have discovered that it wasn't a corpse, but a child acting, was a metaphor for Spain's atavistic backwardness; for a culture in which cruelty was mixed with poverty, a dark country. Because of this message, and the cruelty of scenes like this one, the film was banned by the Spanish Republican Government, and its circulation was halted. The possible subversive capacity of these corpses and their power as criticism, was thus deemed to have been neutralized.

That is why I would claim that the first significant corpses that appear in Spanish war cinema are the ones in Reportaje del movimiento revolucionario en Barcelona ("News on the Revolutionary Movement in Barcelona", 1936), the first report filmed during the war, from July 19th to the 23rd, by Mateo Santos. In this footage, at a certain moment, we can see the crowd gazing at the mummies of several nuns displayed on the entrance stairway of the Church of the Salesas; the voiceover presents these mummies as proof that the nuns were tortured by fellow nuns, an interpretation that seems rather forced.

But perhaps the best-known corpses in the Civil War are those of the children that appeared in the 10th episode of the Russian 


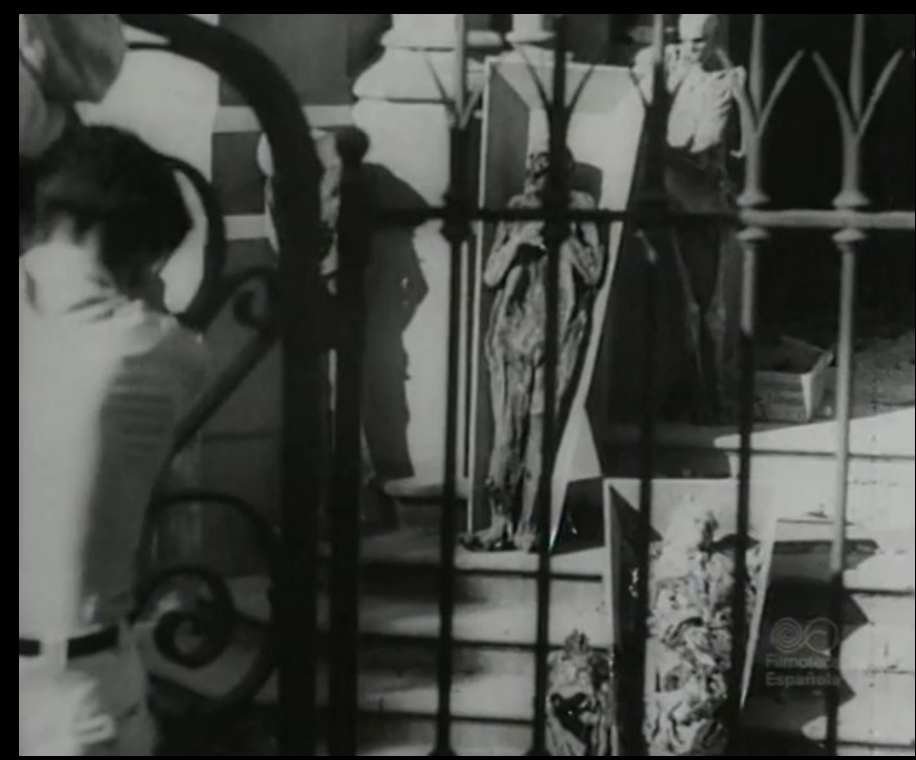

Reportaje del movimiento revolucionario en Barcelona (Mateo Santos, 1936)
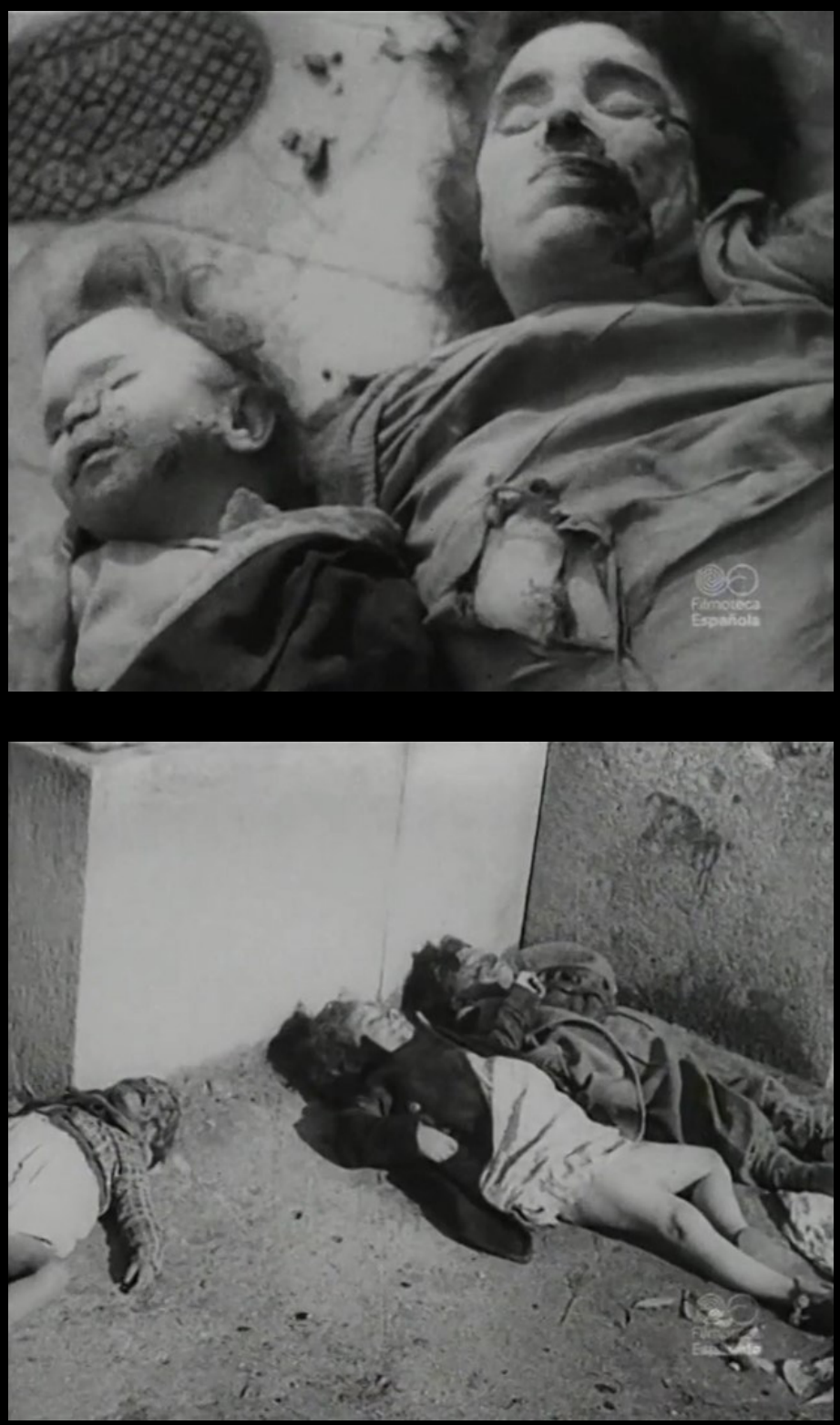
newsreel K Sobitiyam VIspanii (1936).

These corpses, who died from the bombardments of the capital city, were a recurring propaganda motif.

What's interesting is that both images - the one with the nuns and the one with the children were reappropriated for use in cinematographic propaganda by the Nationalist faction, giving them new meaning in other films and newsreels. Thus the corpses became deideologized, to become something that was everyone's property. They were like a kind of blank page onto which any message could be written. In this way, they could be shown as many times as necessary.

All that changed after the Spanish Civil War, when Francoism first decided to use the images of corpses, while pointing the finger at those they claimed were responsible for the deaths, who were none other than the Republican side, whom they dubbed rebellious. In 1940, through a legislative decree, the Francoist faction instituted a Causa General, to be instructed by the Attorney General, regarding the "Red domination" of Spain for the purpose of examining the criminal actions committed throughout the nation during that "Red domination". The Causa General compiled information about the circumstances and details of not only abuses and crimes against people and property committed during the conflict in the Republican zone, but also all kinds of actions carried out by the authorities, the armed and security forces and supporters of the Republican and left-wing governments from the declaration of the Second Spanish Republic onwards. Using their conclusions, a richly illustrated book was published, under the same title (MINISTERIO DE JUSTICIA, 1943). The Francoist authorities did not skimp on any detail, creating a macabre and painful book which, even so, became a best-seller. A best-seller full of corpses.

However, the country's morale had hit rock bottom and Germany was beginning to lose the war, so the Francoist propaganda decided to change its approach and to abandon its bellicose style in favor of a cultural setting featuring white telephones, tulle curtains and sumptuous sets. In literature, romantic novels abounded, while memories of the war (the famous cine de cruzada) that had proliferated in the early 1940 s began to fade away. Corpses disappeared from Spanish cinema to be replaced by charming parties and country clubs, in films like Ella, él y sus millones ("She, He and His Millions", Juan de Orduña, 1944) and Si te hubieses casado conmigo ("If You Had Married Me", Viktor Tourjansky, 1948).

The corpses were too close for comfort, painfully inserted into the country's memory. In 1944, Dámaso Alonso opened his collection of poems Hijos de la ira ("Sons of Anger", perhaps the most important book of poems from the post-war period) with a poem, "Insomnio" ("Insomnia"), which began as follows:

"Madrid is a city of more than a million corpses (according to the last statistics).

At times at night I turn and sit up in this niche in which I have been rotting for 45 years,

And spend long hours listening to the hurricane moan, or the dogs bark, or the light of the moon flow softly.

And I spend long hours moaning like the hurricane, barking like a mad dog, flowing like the milk from the warm udder of a big yellow cow.

And I spend long hours querying God, asking him why my soul slowly rots away,

Why more than a million corpses rot away in this city of Madrid, 

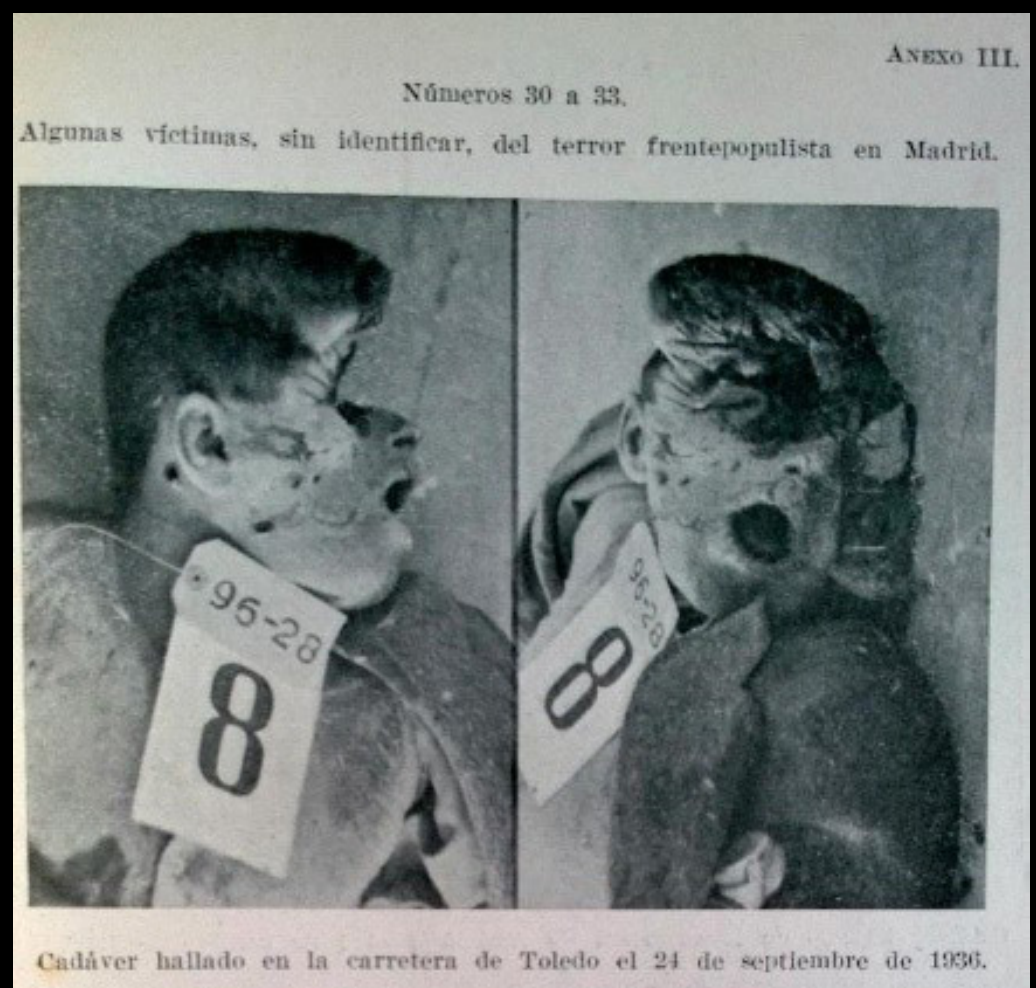

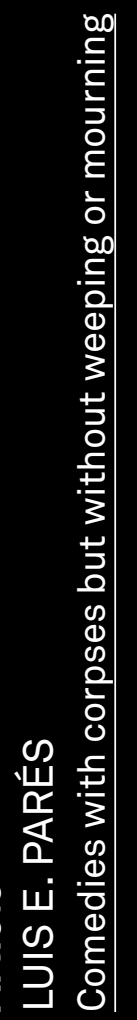

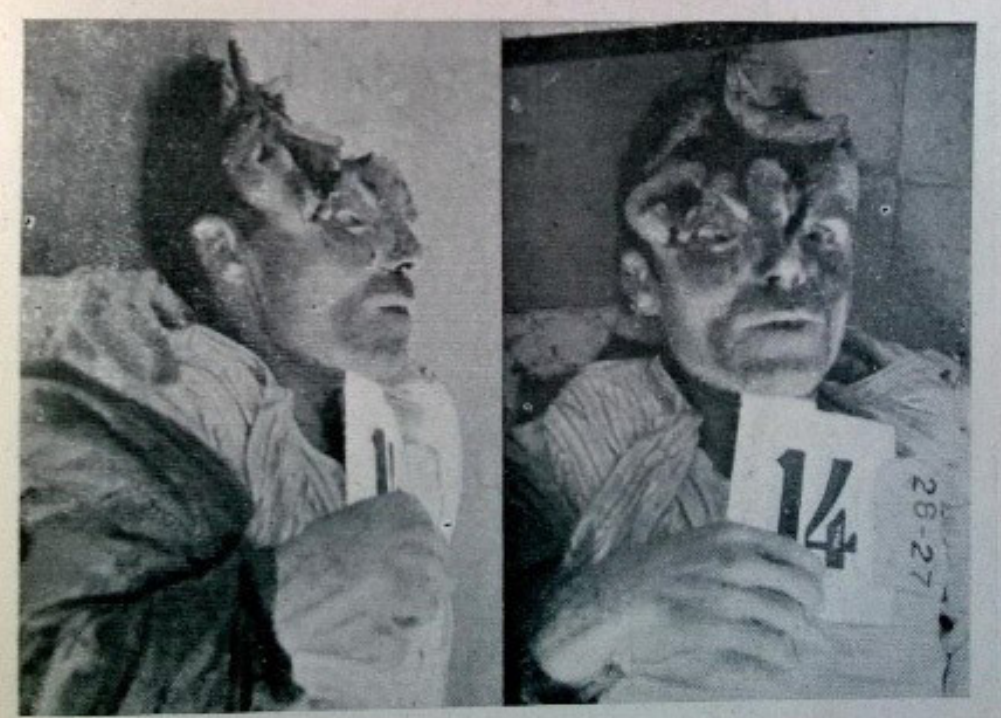

Cadaver hatlado en el campo de "La China" el 19 de keptiembre de 1936.

La dominación roja en España: avance de la información

instruída por el Ministerio Público: causa general (1943)

\section{$\overline{2} \stackrel{m}{\circ}$ \\ 욜 요}


Why a billion corpses rot away

slowly in the world." (included in DEBICKI 1994: 65)

Alonso clearly saw each survivor as the shadow of a dead person, within a city - Madrid - that was surrounded by destruction. Nevertheless, in that same year of 1944, Arsenic and Old Lace (Frank Capra, 1944) premiered in Spain. It was an enormous success and had a great influence among the intellectual classes which could only be compared to the impact garnered by Rebecca (Alfred Hitchcock, 1940). In this sweet, gentle movie, two venerable old ladies murder beggars with the helpful intention of liberating them from their suffering. The discovery of the bodies and the contradiction between murder and the murderers' good intentions all go to produce an amusing vaudeville filled with misunderstandings in which the corpses are not actually seen, but they are the cause of the laughter. The members of the inappropriately named "Other Generation of '27" took note, seeing it as a faucet upon which to build a style that would help them finally work out how to combine a natively Spanish humor (sainete, purism) with a more cosmopolitan humor. Almost all of them began writing plays that starred a corpse.

The first of these was Miguel Mihura, who wrote (with Álvaro de la Iglesia's help) El caso de la mujer asesinadita ("The Case of the Nicely Murdered Lady"), which premiered in 1946. But it was Jardiel Poncela who took this "corpse humor" further with works like Eloisa is Underneath an Almond Tree (Eloísa está debajo de un almendro, 1940), Un marido de ida y vuelta ("A Round-Trip Husband", 1939) and Las siete vidas del gato ("The Cat's Seven Lives", 1943), all plays that were adapted for cinema. Thus it should come as no surprise that comedy with corpses appeared in Spanish cinema sooner or later.

Concurrently with these comedies,
Spanish cinema also showed glorious corpses in its great heroic epic stories, almost always at the end of the storyline and as a consequence of a tempestuous but eventually redeemed life. Let's not forget that these corpses were nearly always played by Aurora Bautista: Love Crazy (Locura de amor, Juan de Orduña, 1948), Trifles (Pequeñeces, Juan de Orduña, 1950), Agustina of Aragon (Agustina de Aragón, Juan de Orduña, 1950), among others. Thus we could say that the first film to really make the corpse into the narrative and comedy catalyst after Jardiel was Usted puede ser un asesino ("You Can Be a Murderer", 1961), by José María Forqué, an adaptation of a novel by Alfonso Paso.

This playwright was one of the pillars on which the consumer cinema of Francoism was built, in his threefold capacity as adapted author, screenwriter and director. He was also the son-in-law of Jardiel Poncela, which meant he was always accused of using the plots his father-in-law had left unfinished. Alfonso Paso represents - as no-one else does the tastes of the middle class of the 1950 s and ' 60 s, writing as he did an escapist theater that was devoted to entertaining people and making them laugh. He was perhaps the most prolific author during the Franco regime, and at one point in 1968, seven of his plays were staged in the theaters at the same time.

In the aforementioned film, two businessmen (played by Alberto Closas and José Luis López Vázquez) decide to send their wives off to the countryside in order to throw a party with their secretaries. During the party preparations, a stranger enters the house, and after a clumsy struggle, he trips over and dies. The party becomes less important, as what they need to do is to hide the body, something that becomes more urgent as time passes, since their respective wives decide to 
come home earlier than expected.

Here the corpse is the catalyst not so much for laughter (José Luis López Vázquez gives free rein to his renowned comic histrionics from the very outset of the film) but for hypocrisy. Perhaps one of the film's implicit messages (and one that was very much in accord with the moral tastes of the time) was that being unfaithful to your wife was as bad as hiding corpses in the closet. That is why, no doubt, the action of the movie takes place in Paris, where immorality is possible, and not in chaste Spain.

This type of corpses, comedic and frivolous, appeared in many comedies, such as Un marido de ida y vuelta ("A Round-Trip Husband", Luis Lucia, 1957) and Crimen imperfecto ("Imperfect Crime", Fernando Fernán Gómez, 1970), in which the corpse always demonstrated that loose living (the ménage à trois insinuated in the first one and the out-of-wedlock relationship in the second) would be paid for dearly. However, not all corpses upheld the prevailing morality. A few filmmakers realized that the combination of comedy and corpse was viewed favorably by the authorities, and decided to use this narrative structure to bring humor to the land of darkness. In that brief but brilliant period of Spanish dark comedy, all the films contain a corpse and a denunciation: The Little Apartment (El pisito, 1958) and The Little Coach (El cochecito, 1960) by Marco Ferreri; Plácido (1961) and The Executioner (El verdugo, 1963) by Luis García Berlanga; Entierro de un funcionario en primavera ("Burial of a Civil Servant in Spring", 1958) by José María Zabalza and Strange Voyage (El extraño viaje, 1964) by Fernando Fernán Gómez. In all of them, the corpse exposes a despicable situation that involves mutual envy, financial hardship and moral despair that must be hidden and covered up once again. The problem is that these films could not be given normal premieres, due to the administrative obstacles imposed (and which gave them a low classification that limited the circuit of movie theatres where they could be screened, for example). All of them are considered masterpieces today, but they had to be rescued by the critics some time after their commercial release.

On November 20th, 1975, Franco died and the Transition period began, and with it a new window opened for reflection on the country's political future, but also on its recent history. It is odd that the Transition began with an illustrious corpse - that of the Head of State himself, with an uninterrupted 36-hour broadcast on $\mathrm{TVE}^{3}$ that showed the mortuary chapel and the funeral cortege. The images - a 3-camera setup which featured a long shot of the procession, a close-up of the person who faced the coffin to bid the deceased farewell and a shot of the corpse - have been shown repeatedly in all kinds of documentaries, most notably in La Transición ("The Transition", 1995) by Victoria Prego, a documentary series that established the official narrative for that political period.

The historical importance of these images was so obvious that they soon began to be parodied, as in the film Hic Digitur Dei (Antoni Martí, 1976), a Super 8 film shot in the underground environment of Barcelona. The film was devised as a parable about the sentimental education of a generation of Spaniards who were raised on radio soaps and romantic quizzes in magazines. At a particular point in the film, we witness a grotesque dramatization of Franco's mortuary chapel in which toothless soldiers, bearded ballerinas in tutus, babies with bottles of whiskey and a parody of the Marquis of Villaverde slowly approach the coffin where the dictator lies in his death throes.

However, the cinema of the Transition did not prove to be as 

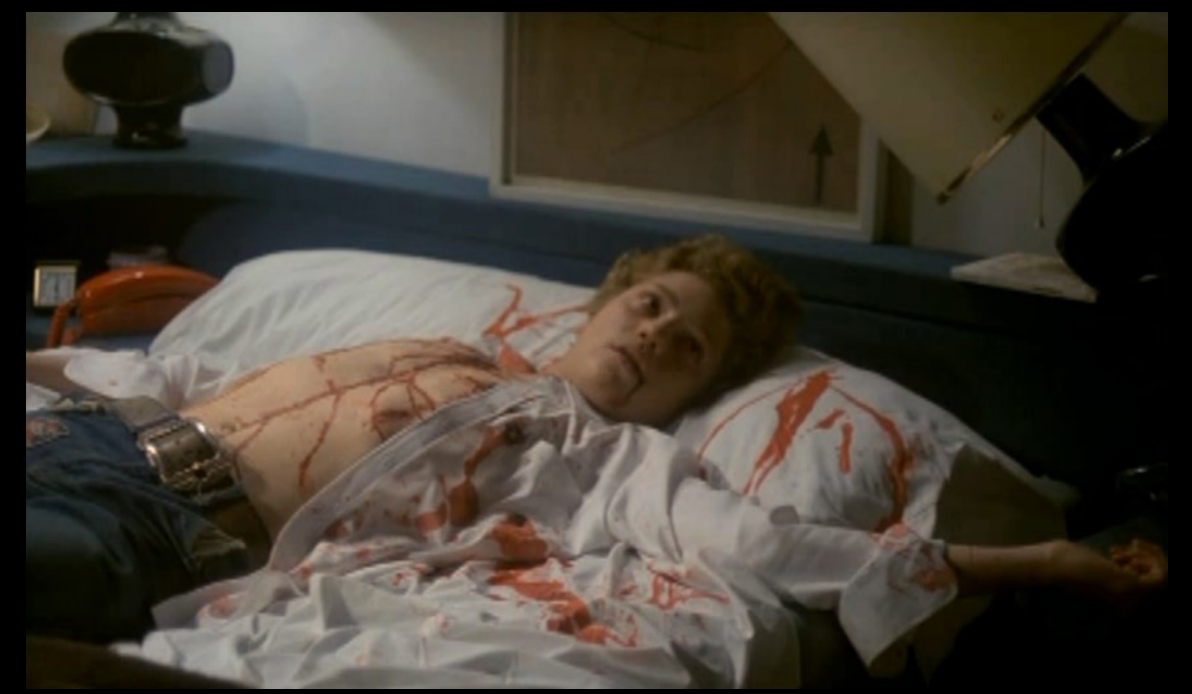

Confessions of a Congressman (Eloy de la Iglesia, 1979) 
interested in interpreting the figure of Franco as it was in neutralizing his followers. Many of the fears that tormented the country had to do with the threat of the far right, whose violence and extortion filled the newspapers. Up until 1979, the far right killed 66 people, which cinema duly reflected in films like Seven Days in January (Siete días de enero, Juan Antonio Bardem, 1979) and Blindfolded Eyes (Los ojos vendados, Carlos Saura, 1978). The first film to show this violence was Black Litter (Camada negra, Manuel Gutiérrez Aragón, 1977), which symptomatically opens with an attack on an art gallery where the Equipo Crónica's paintings and posters are on display. The film takes a metaphorical tone, telling the story of an authoritarian woman who incites and indoctrinates a group of young people into violence and the ideology of the far right. Their cover is that they are members of a church choir.

In the last scene, the youngest boy in the group, a teenager, goes off into the forest with his girlfriend, and when they start kissing and undressing, he picks up a rock and smashes the young girl's face, all the while screaming "Spain". After the murder, he digs a hole, throws in the corpse and plants a tree, a scene with clear symbolic connotations. What will be born out of that tree? Is the seed of our youth a corpse?

Another film, released two years later, is even more explicit with regard to its corpse and its meaning - Confessions of a Congressman (El diputado, Eloy de la Iglesia, 1979). The film, narrated via a long flashback, shows Roberto Orbea, a member of the Spanish Communist Party, at the moment when he is about to be appointed Secretary General of the party. However, that same night, an extreme right-wing terrorist cell blackmails him by killing his lover. Roberto Orbea is gay, which compels him to double secrecy - both political and sexual. The scene when the corpse is discovered (Roberto Orbea's lover is played by José Luis Alonso, the same actor who played the teenage murderer in Black Litter) is quite explicit:

\section{Commando Chief: Surprised.}

Roberto Orbea: Why? Why did they do this? I came to meet you before the deadline you gave me... Are you going to kill me, too?

Commando Chief: No. For us, it's much more fun that a leftwing leader should have to explain how a corpse turned up in his apartment. In his secret apartment. We wish you lot of luck tomorrow at your congress. You're going to be elected General Secretary, right?

\section{Congratulations.}

However, Tatín's corpse was not directed towards the far right, but the parliamentary left. And more specifically, at the Spanish Communist Party. Eloy de la Iglesia was, just like his character, both a member of the Communist Party and gay. He had experienced the homophobia of his fellow party members, and had felt compelled to adopt the same emotional secrecy as his character. On the day of the premiere, he sat La Pasionaria and Carrillo in the front row and confronted them with their own contradictions those of a party that wanted political reform without focusing on individual freedoms.

But the film which took the metaphor of Spain as a country full of corpses furthest came from the margins of the industry. The very title Cada ver es... (Ángel García del Val, 1981) establishes the theme of the movie: one man's strange relationship with death. It is a documentary that shows the work shift of Juan Espada, who was responsible for the care and maintenance of the cadavers at the Faculty of Medicine of Valencia.

"His working routines and his comments reveal the emotional, 
political and sexual repression that

Francoism exerted upon the man

(and who becomes a metaphor for the Spanish population) who ended

up living his life among lifeless

bodies" (LÓPEZ CARRASCO and

PARÉS, 2017).

At one point, he tells of his experiences as a soldier in the Republican army, and the time when he saw a field covered in corpses and he ran away, gripped by an infinite fear. But then, as the main character points out, he got used to corpses. The film clearly shows that all Spaniards at that time were corpses, and that the memory of the Civil War could only be a memory of death, which somehow touches on Dámaso Alonso's reflections in his poem.

The film is not only explicit thematically, but above all, formally. There are dozens of close-ups of cadavers and we see, for example, Espada sawing through a skull and splitting it in two. We see cadavers of elders, and babies too, while among them there is this ordinary man who works with them and handles them quite naturally, as if working with cadavers was something completely normal. Though for him it is and, as he admits, he sometimes talks to them and apologizes before doing something to them that they wouldn't have liked when they were alive. Cada ver es... might be the most radical work out of all the cinema of the Transition. That is why the persecution to which it was subjected somehow serves as an example in terms of the links between power and cinema.

"The state gave this thematically and formally radical film an $S$ rating (denoting films with high erotic content), which meant that its circulation was limited. After the movie's producers appealed this, the state finally denied them the possibility of a commercial premiere because the movie had been shot in $16 \mathrm{~mm}$, which 'distanced' it from the quality required for the commercial circuit. This subterfuge, which represents an administrative excuse for blocking disturbing movies, overrode all documentary and experimental practice by means of bureaucratic channels. Until then, all documentary production had been shot in $16 \mathrm{~mm}$, for financial reasons. According to Pena and Cerdán, Cada ver es... became a 'lugubrious metaphor for what happened to the most nonconformist, radical cinema on the peninsula"" (LÓPEZ CARRASCO and PARÉS, 2017).

From that point on, corpses disappeared from Spanish cinema, and what appeared instead were images of a non-bellicose past, comedies featuring upper-class characters or academic literary adaptations which used the adapted books as no more than backcloths on which to construct a comedy of manners of the past. The cinema of the 1980s was an attempt to forge itself in the image and likeness of European academicism, leaving behind not only the popular origins of Spanish cinema, but also the strongest creative veins of our culture.

The Spanish cinema of the 1980s disengaged from current times, and ceased to be an echo-chamber or a loudspeaker for society's concerns. It was an aspirational form of cinema, one that didn't reflect the society that we were, but the one we dreamed of being. In this way, cinema turned into the finest representation of the socialdemocratic philosophy that ruled the country: Spain had left behind the darkness and finally embraced modernity. This state of mind was endorsed by the international success of the Olympic Games and the Universal Exposition of Seville. The message was clear: Spain had finally become a country just like any other.

Gradually, corpses started appearing 


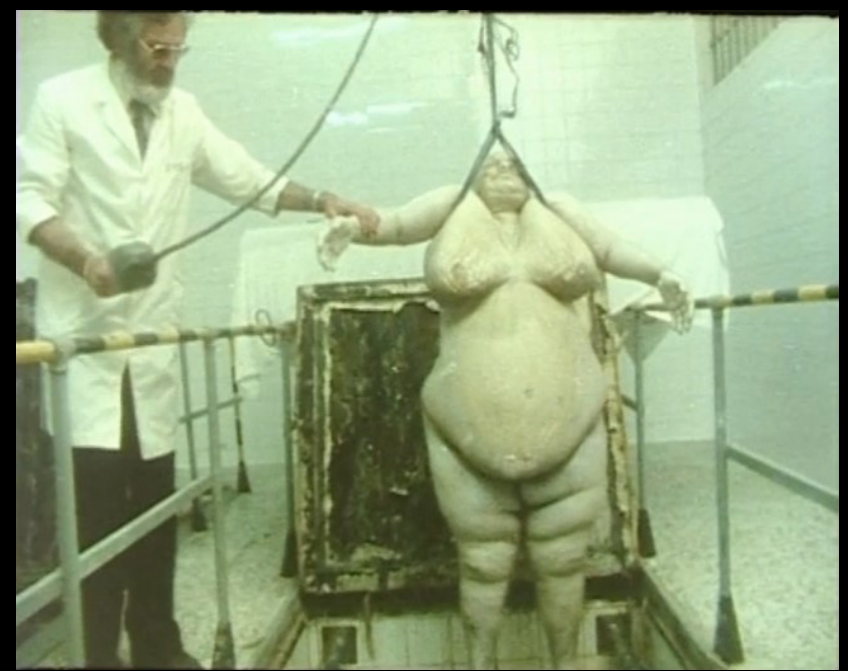

Cada ver es... (Ángel García

del Val, 1981)
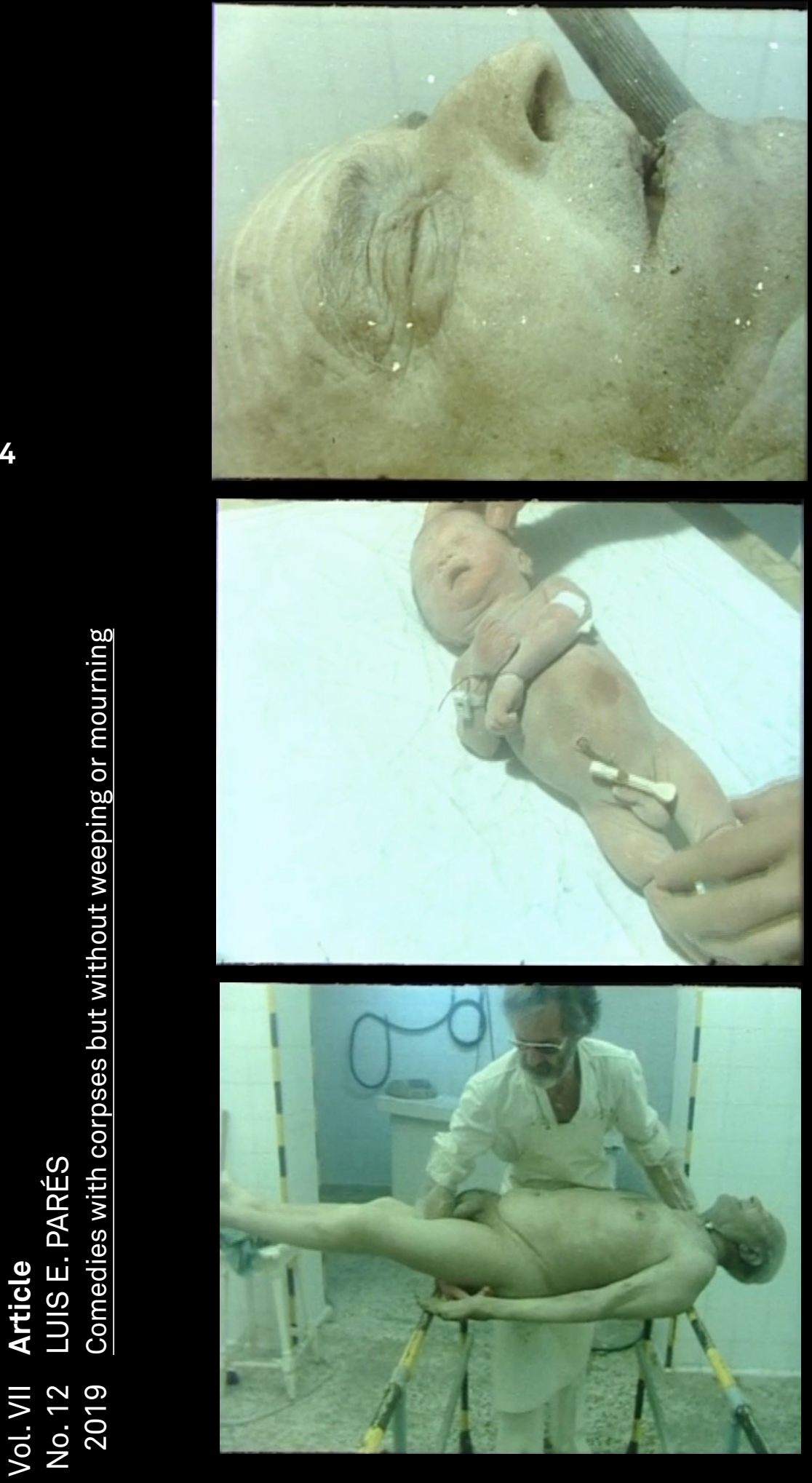
in Spanish cinema, always linked with that tradition of the 1950s and ' 60 s in which corpses made people laugh and not think. 1990 saw the release of Aquí huele a muerto... (;Pues yo no he sido!) ("It Smells Like Death... It Wasn't Me!", Álvaro Sáenz de Heredia), starring the popular comedy duo Martes y Trece in a parody of Dracula with living dead who believe they're actually dead, and vice versa. The film was a huge box office success, which they continued with their next parody, this time of heist movies, El robobo de la jojoya ("The robbebbery of the jejewel", Álvaro Sáenz de Heredia, 1991).

However, it wasn't until 1997 that corpses came to the forefront again. Excuse Me Darling, But Lucas Loved $\mathrm{Me}$ (Perdona bonita, pero Lucas me quería a mí) was the second movie by Félix Sabroso and Dunia Ayaso. The plot revolves around the discovery of the body of Lucas, the roommate of the three protagonists, all gay men who were madly in love with him, each of them believing that he was the one whom Lucas had loved. One of the three must be the murderer, but which one? This situation was the starting point for a plot based on clichés that stereotyped gays, involuntarily turning them into figures of fun. It was also, once again, the mise-en-scène for a youth whose leisure habits had completely changed, and for whom nightlife, clubs and drugs had become a vital escape.

The important aspect of Excuse Me Darling... wasn't the plot but the aesthetics. The film was described in its premiere as "crazy", "wild" and "rowdy", adjectives that had also been used to describe Almodóvar's early films. But unlike him, this movie was unable to paint a portrait of a country that was changing, since Excuse Me Darling... tended towards exaggerations which made any kind of reflection impossible. The final scene, in which the three friends get rid of the body to then go on with their lives, is presented to us, nonetheless, as highly symptomatic of that choice not to face problems directly.

Shortly after that, an attempt was made to place corpses at the center of a plot once again, in order to highlight the country's socioeconomic hardships. Javier Maqua was the director, and Chicken Skin (Carne de gallina, 2002) was the film. It tells of how a family, whose father has just died, is forced to conceal the body (and the death) while they are waiting (for several anxious days) for a life-saving loan taken out by the deceased to arrive. The story takes place in a depressed mining town in Asturias where industrial reconversion has filled the bars with jobless people with no future, a very different scenario from the "Spain is doing well" that the Partido Popular (Popular Party) government was pushing as its slogan. Thus, Maqua not only linked with the tradition of Ferreri, Berlanga and Azcona, he also made an openly political film at a time when Spanish social cinema seemed to be a poor, ugly imitation of Ken Loach's cinema, but without its power or faith.

However, Maqua's idea of reclaiming the corpse as something subversive, which by making us laugh revealed our own contradictions, had no continuity. Corpses were reclaimed for comedy, but in Alfonso Paso's festive and frivolous style, albeit with updated aesthetics. Suddenly, the corpses in Spanish cinema became modern corpses. No surprise, then, that the three directors who had been awarded the label of "modern" - Pedro Almodóvar and the Félix Sabroso/ Dunia Ayaso duo - continued to explore comedy with corpses. Almodóvar with Volver (2006), which was devised as a plot twist on What Have I Done to Deserve This? (¿Qué he hecho yo para merecer esto?, 1984), in which Penélope Cruz's character hides her husband's body in the freezer of a neighbor's 


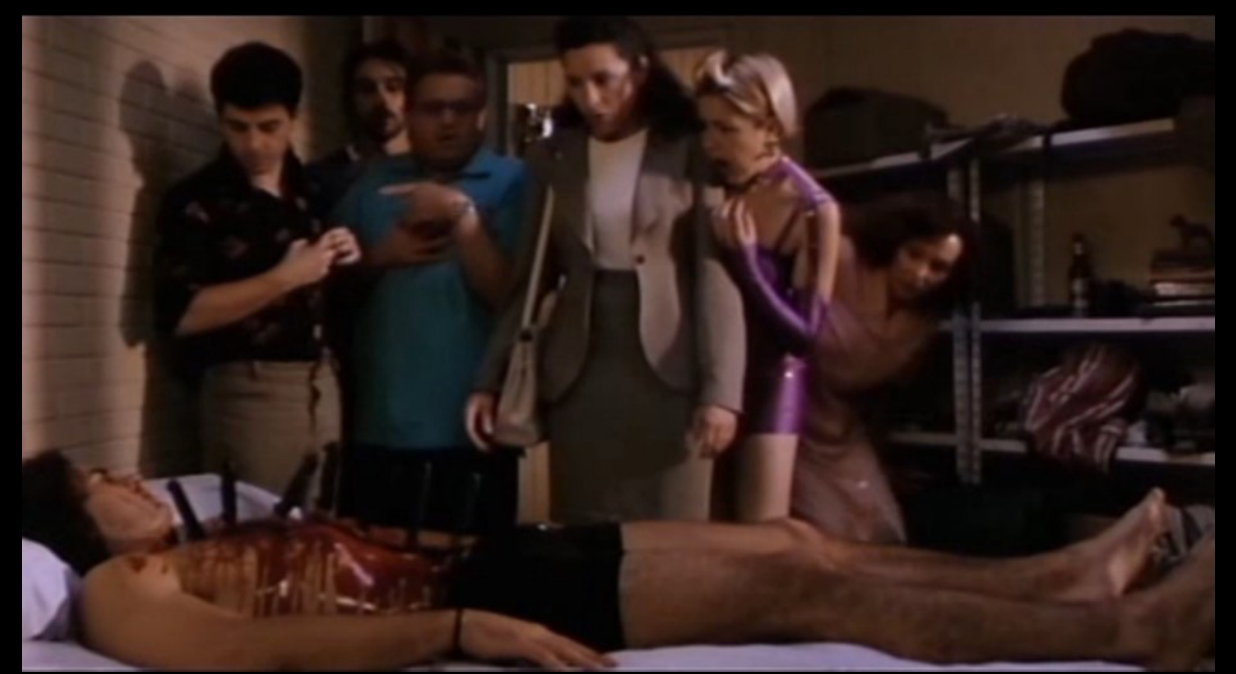

Excuse Me Darling, But Lucas Loved Me (Félix Sabroso and Dunia Ayaso, 1997)

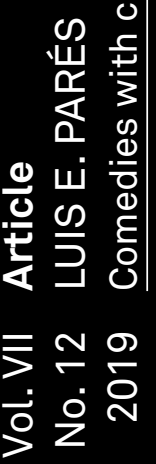


restaurant, and they can't get rid of it because of the presence of a film crew who have lunch and dinner in the house. Meanwhile, the Sabroso/Ayaso duo made Chill Out! (Descongélate!, 2003), in which a film director passes away in the living room of the actor who's going to play the lead in his film, and who decides to hide the body until he signs the contract. But not even Volver managed to turn the comedy of manners into a portrait of the fringes, nor did the filmmaking duo succeed in getting people to think about job insecurity.

As a result, it is not surprising that Paco León, the contemporary filmmaker who has most in common with the aforementioned directors, revived the theme of comedy with corpses in Carmina y amén ("Carmina and Amen", 2014). This film echoes, unconsciously, the plot of Chicken Skin: a mother and a daughter have to hide the father's body for an entire weekend to be able to collect the deceased's bonus. Like Maqua, León tries to normalize the use of a non-normative accent, in this case Andalusian. But there is no political comment here, just an updating of the sainete of the comedy of manners, together with a bit of self-righteous social reflection.

As we have seen, in Spanish culture, looking at a corpse face to face is an act of subversion, because what you should do is to watch over them and pray for them, but not look at them. Hence the lack of charismatic corpses in Spain, of well-known corpses or of corpse worship. For example, José Antonio Primo de Rivera was the most adored, best-known dead man from the Franco regime, but we never saw his corpse. What we did see was the spectacle of his funeral, in accordance with a carefully-executed script. His remains were exhumed from the prison in Alicante and carried to El Escorial on the shoulders of groups of Falangists, supported by many others who carried torches. José Antonio is proof that we don't dare to look at the corpse, but we do like going to the funeral. In that act of looking away, there's room for jokes, but not for reflection.

As a final thought, this might be due to the never-ending conversation in Spain about what to do with the corpses from the Civil War and the immediate postwar period that are still buried in ditches. By not wanting to open wounds, the wounds are never closed. In some way, talking about a corpse in Spain is like talking about the million corpses (in José María Gironella's successful phrase) that the Civil War produced, only half of whom have been given a dignified burial. These corpses are a ghostly, terrifying presence, and as we apparently believe, the best remedy for fear is laughter.

Translated by Daniela Torres Montenegro (See original text at the end of the journal) 
DEBICKI, Andrew P. (1994). Spanish Poetry of the Twentieth Century: Modernity and Beyond. Lexington: University Press of Kentucky.

HOLDEN, Anthony and HOLDEN, Ben (eds.) (2014). Poems that Make Grown Men Cry: 100 Men on the Words that Move Them. London: Simon \& Schuster.

LÓPEZ CARRASCO, Luis and PARÉS, Luis E. (2017). Confort y conflicto (y II). De cómo el cine español se desconectó de la realidad en los años ochenta. CTXT-Revista Contexto, 135, September 22nd, 2017. Retrieved from: https://ctxt.es/es/20170920/Culturas/15119/cinesa\%C3\%B10s-ochenta-transicion-franquismo-ley-miro.htm [access: July 17th 2019]

MINISTERIO DE JUSTICIA (1943). La dominación roja en España: avance de la información instruída por el Ministerio Público: causa general. Madrid: Ministerio de Justicia. 
Parés

\title{
Comedias con cadáver pero sin llanto ni duelo
}

El artículo interroga la problemática figuración del cadáver en la historia del cine español y particularmente en el género de la comedia. Partiendo de la constatación de la centralidad de la muerte y de sus representaciones en la cultura española, el autor indaga en los modos de presencia de los cadáveres en nuestro cine y cómo el acercamiento a este motivo traduce una determinada actitud ante la historia y cifra una mirada crítica o bien una actitud escapista por parte de los cineastas y las películas. Tras dibujar una genealogía de sus representaciones, tomando como primeros cadáveres relevantes los cuerpos de los caídos en la Guerra Civil, el texto construye una historia sintomática de las formas de representación del cadáver en el cine español de posguerra, reparando en el desplazamiento de la figura hacia el territorio cómico y su evolución, desde la voluntad evasiva y despolitizada hacia el territorio de la negrura y la penetración crítica. El autor también señala la relevancia de la representación del cadáver en el cine de la Transición y constata la desaparición de la figura con la consolidación del cine de la democracia. Finalmente, la representación del cadáver queda fijada como una herramienta significativa para constatar la carga crítica del cine español en relación a su historia y a su presente.

\author{
Palabras Clave \\ CADÁVER \\ CINE ESPAÑOL \\ HISTORIA \\ HISTORIA DEL CINE \\ COMEDIA \\ CULTURA ESPAÑOLA \\ MUERTE \\ COMEDIA NEGRA \\ TRANSICIÓN
}

Luis E. Parés (Madrid, 1982). Historiador y documentalista. Ha publicado los libros Notes sur l'emigrationEspagne 1960. Apunts per a una pel-lícula invisible y Filmar el exilio desde Francia. Como programador, ha trabajado en diferentes festivales e instituciones, como Zinebi, Punto de Vista, el Festival Internacional de Cine de Sevilla y Filmoteca Española, y ha coordinado el programa diario de RTVE Historia de nuestro cine. Su trabajo se ha centrado en el cine español, particularmente en el "segundo exilio» y en la construcción de un nuevo relato cultural basado en el rescate de imágenes ignoradas por la historiografía tradicional. 
«L'Espagnol souffre d'un handicap: il n'est pas très doué pour la mise en scène cinematographique. Handicap qu'il compense largement par la richesse de son expression picturale.»

Luc Moullet

En la cultura española, la muerte siempre ha tenido una presencia constante. Pero sin embargo, la cultura española siempre ha usado la muerte como un símbolo para la reflexión moral. Desde las coplas de Jorge Manrique al verso «serán ceniza pero tendrán sentido" de Quevedo, pasando por las vanidades de Valdés Leal o las esculturas de Gaspar Becerra, la cultura española, dotada de un gran poder icónico, no ha dejado de reflexionar sobre la fugacidad de la gloria, la inconsistencia de las emociones o incluso lo absurdo de las ataduras terrenales. Y en ese juego de representación moral, el cadáver ha sido una de las metáforas más presentes.

Fue la unión de la carnalidad de la representación y la simbología moral de las imágenes lo que impresionó a Gautier y a Manet en sus visitas al Museo del Prado en el siglo XIX. Éste último, en un carta a Baudelaire, definió el arte español como bello y terrible. Sin embargo, esa iconicidad, bella y terrible, de la pintura española, que no recelaba de pintar un cadáver, no pasó al cine español, cuyos autores han buscado su filiación más en el teatro popular (sainetes, astracanadas) que en la escuela pictórica. Quizá a esto se deban los problemas que el cine español ha tenido a la hora de representar cadáveres.

Es difícil saber cuál fue el primer cadáver del cine español, debido a la escasez de material que nos ha llegado (se calcula que el $94 \%$ del cine hecho en España antes de la Guerra Civil se ha perdido). En el cine mudo hay cadáveres ilustres, como el del Asesinato y entierro de don José Canalejas (1912), un cortometraje realizado por Enrique Blanco y Adelardo Fernández Arias que reconstruía el atentado contra José Canalejas, para poder difundir la noticia de su muerte. Es curioso señalar que el papel del asesino lo interpreta José Isbert, unido para siempre en nuestro imaginario de espectadores al oficio de verdugo.

Quizá el siguiente eslabón importante en esta cadena sea el cadáver del bebé en Las Hurdes (1933), de Buñuel, cadáver que es transportado sobre el agua en una caja de madera. Este cadáver, que investigaciones posteriores parecen haber averiguado que no era tal, sino un niño pequeño actuando, era una metáfora del atraso atávico de España, de una cultura donde la crueldad y la pobreza se mezclaban, de un país oscuro. Por este mensaje, y por la crueldad de escenas como esta, la película fue prohibida por el Gobierno de la República, y su difusión cercenada. La posible capacidad subversiva de estos cadáveres, su potencia como denuncia, se vio de este modo neutralizada.

Es por ello que me atrevo a decir que los primeros cadáveres relevantes que aparecen en el cine de la Guerra español son los que aparecen en Reportaje del movimiento revolucionario en Barcelona (1936), el primer reportaje rodado durante la guerra, del 19 al 23 de julio, por Mateo Santos. Allí en un momento dado se ve, en la Iglesia de las Salesas, cómo la multitud contempla las momias de unas monjas expuestas en la escalinata de entrada; la locución presenta estas momias como prueba de que las monjas eran torturadas por sus mismas compañeras, en una interpretación quizá un poco forzada.

Pero quizá los cadáveres más conocidos de la Guerra Civil son los cadáveres de niños que aparecieron en el número 10 del noticiario ruso $K$ Sobitiyam VIspanii (1936). Esos cadáveres, ocasionados por los bombardeos sobre la capital, fueron un motivo de propaganda recurrente.

Lo interesante es que ambas imáge- 
nes, la de las monjas y la de los niños, fueron reapropiadas por la propaganda cinematográfica afín al bando nacional, apareciendo resignificadas en otras películas y otros noticiarios. Los cadáveres, de este modo, pasaron a ser algo desideologizado, propiedad de todos. Eran una especie de hoja en blanco sobre la que se podía escribir cualquier mensaje. Y de ese modo, se podían mostrar las veces que hiciesen falta.

Todo esto cambió tras la Guerra Civil, cuando el franquismo decidió primero poner los cadáveres sobre la mesa, adjudicándoles un responsable, que no era otro que el bando republicano, al que ellos llamaban faccioso. En 1940, mediante un Decreto-Ley, se abrió la Causa General Instruida por el Ministerio Fiscal sobre la «dominación roja» en España, para instruir los hechos delictivos cometidos en todo el territorio nacional durante la «dominación roja». La Causa General recopiló información sobre las circunstancias y detalles no solamente de abusos y crímenes contra personas y bienes cometidos durante la contienda en la zona republicana, sino todo tipo de acciones emprendidas por las autoridades, fuerzas armadas y de seguridad y partidarios de los gobiernos republicanos y de izquierdas desde la instauración de la Segunda República. Con sus conclusiones, se publicó un libro, con el mismo título, muy ilustrado (MINISTERIO DE JUSTICIA, 1943). Las autoridades franquistas no escatimaron ningún detalle, creando un libro macabro y doloroso, que a pesar de ello, se convirtió en un best-seller. Un best-seller lleno de cadáveres.

Sin embargo, la moral del país estaba por los suelos y Alemania empezaba a perder la guerra, por lo que la propaganda del franquismo decidió cambiar de rumbo, y abandonar las proclamas beligerantes en pos de una producción cultural de teléfonos blancos, de cortinas de tul y fastuosos decorados. La literatura se llenó de novelas románti- cas, mientras que los recuerdos de la guerra (el famoso "cine de cruzada») que tanto proliferaron en los primeros años cuarenta iban desapareciendo. Los cadáveres desaparecieron del cine español y aparecieron las fiestas galantes y los clubes de campo en películas como Ella, él y sus millones (Juan de Orduña, 1944) o Si te hubieses casado conmigo (Viktor Tourjansky, 1948).

Los cadáveres estaban demasiado cerca, insertos dolorosamente en la memoria del país. Dámaso Alonso abría su poemario de 1944, Hijos de la ira (quizá el libro de poemas más importante de la posguerra), con un poema, "Insomnio», que comenzaba con los versos:

"Madrid es una ciudad de más de un millón de cadáveres (según las últimas estadísticas).

A veces en la noche yo me revuelvo y me incorporo en este nicho en el que hace 45 años que me pudro,

y paso largas horas oyendo gemir al huracán, o ladrar los perros, o fluir blandamente la luz de la luna.

$Y$ paso largas horas gimiendo como el huracán, ladrando como un perro enfurecido, fluyendo como la leche de la ubre caliente de una gran vaca amarilla.

Y paso largas horas preguntándole a Dios, preguntándole por qué se pudre lentamente mi alma,

por qué se pudren más de un millón de cadáveres en esta ciudad de Madrid,

por qué mil millones de cadáveres se pudren lentamente en el mundo.» (ALONSO, 1990: 81)

Estaba claro que Alonso veía en cada superviviente la sombra de un muerto, en una ciudad, Madrid, cercada por la destrucción. Sin embargo, ese mismo año de 1944 se estrenó en España Arsénico por compasión (Arsenic and Old Lace, Frank Capra, 1944), que fue un gran éxito popular y que ejerció un gran 
influjo, solo comparable al de Rebeca (Rebecca, Alfred Hitchcock, 1940), entre la clase intelectual. En esa amable película, dos venerables ancianas asesinan mendigos con la saludable pretensión de liberarles de todo sufrimiento. Del hallazgo de los cadáveres y de la contradicción entre el asesinato y las buenas intenciones de las asesinas, nace un divertido vodevil lleno de equívocos donde los cadáveres no se ven pero son motores de la risa. Los miembros de la mal llamada "Otra Generación del 27» tomaron nota al encontrar una espita sobre la que construir un estilo que resolviese la ecuación que siempre les había condenado: la unión de un humor nativamente español (sainete, casticismo) y un humor más cosmopolita. Casi todos ellos empezaron a escribir obras de teatro protagonizadas por un cadáver.

El primero fue Miguel Mihura (con la ayuda de Álvaro de la Iglesia), que escribió El caso de la mujer asesinadita, estrenada en 1946. Pero fue Jardiel Poncela quien más lejos llevó el «humor de cadáver» con obras como Eloísa está debajo de un almendro (1940), Un marido de ida y vuelta (1939) o Las siete vidas del gato (1943), obras de teatro adaptadas al cine. Por eso no es de extrañar que la comedia con cadáver apareciese en el cine español tarde o temprano.

En paralelo a estas comedias, el cine español mostraba cadáveres gloriosos, en sus grandes epopeyas heroicas, casi siempre al final de la trama y como consecuencia de una vida tormentosa y finalmente redimida. No hay que olvidar que estos cadáveres estaban casi siempre encarnados por Aurora Bautista: Locura de amor (Juan de Orduña, 1948), Pequeñeces (Juan de Orduña, 1950), Agustina de Aragón (Juan de Orduña, 1950)... Por ello se puede decir que la primera película que realmente hace del cadáver el detonante narrativo y cómico en la estela jardieliana es Usted puede ser un asesino
(1961), de José María Forqué, adaptación de una novela de Alfonso Paso.

Este dramaturgo fue uno de los pilares sobre los que se erigió el cine de consumo del franquismo, en su triple condición de autor adaptado, guionista y director. Era además el yerno de Jardiel Poncela, por lo que siempre se le acusó de aprovecharse de las tramas que su suegro había dejado inconclusas. Alfonso Paso representa como nadie los gustos de la clase media de los años cincuenta y sesenta, escribiendo un teatro de evasión, dedicado a entretener y a hacer reír. Fue quizá el autor más prolífico del franquismo, llegando a mantener en cartel en 1968 siete obras a la vez.

En esta película, una pareja de empresarios interpretados por Alberto Closas y José Luis López Vázquez deciden mandar a sus mujeres al campo para organizar una fiesta con sus secretarias. Durante los preparativos de la fiesta, un extraño entra en la casa, $y$ tras un torpe forcejeo, se tropieza y muere. La fiesta pasa a segundo plano, y lo que hay que hacer es ocultar el cadáver, tarea cada vez más apremiante, pues las respectivas mujeres deciden regresar a la casa antes de tiempo.

Aquí el cadáver es el detonante no tanto de la risa (José Luis López Vázquez da rienda suelta a su conocido histrionismo cómico desde el mismo inicio de la película) sino de la hipocresía. Quizá uno de los mensajes implícitos de la película, muy al gusto de la moral de la época, sea que ser infiel a tu mujer equivale a esconder cadáveres en el armario. Seguramente por ello la acción de la película está localizada en París, donde el libertinaje es posible, y no en la casta España.

Este tipo de cadáveres, cómicos y frívolos, aparecieron en muchas comedias, como Un marido de ida y vuelta (Luis Lucia, 1957) o Crimen imperfecto (Fernando Fernán Gómez, 1970), en las que siempre el cadáver demostraba 
que la libertad de costumbres (el insinuado ménage à trois de la primera, la relación fuera del matrimonio de la segunda) se pagaba cara. Sin embargo no todos los cadáveres apuntalaban la moral imperante. Unos pocos cineastas se dieron cuenta de que la unión entre comedia y cadáver estaba bien vista por las autoridades y decidieron usar ese mismo esquema narrativo llevando el humor al terreno de la negrura. En ese ciclo breve pero brillante del humor negro español, todas las películas contienen un cadáver y una denuncia: El pisito (1958) y El cochecito (1960), de Marco Ferreri; Plácido (1961) y El verdugo (1963), de Luis García Berlanga; Entierro de un funcionario en primavera (1958), de José María Zabalza y El extraño viaje (1964), de Fernando Fernán Gómez. En todas ellas el cadáver desenmascara un contexto ruin de envidias cruzadas, miserias económicas y desolación moral que ha de ser de nuevo escondida y tapada. El problema es que estas películas no pudieron ser estrenadas con normalidad, debido a las trabas administrativas que les imponían (les daban una clasificación baja que les limitaba el circuito de cines a los que podían aspirar, por ejemplo). Todas ellas son hoy consideradas obras maestras, pero han tenido que ser rescatadas por la crítica tiempo después de su estreno comercial.

El 20 de noviembre de 1975 murió Franco y comenzó la Transición y con ella se abrió una nueva ventana para la reflexión, sobre el futuro político del país, pero también sobre su historia reciente. Es curioso que la Transición comenzase con un cadáver egregio, el del propio Jefe del Estado, con una emisión ininterrumpida de 36 horas de TVE, en la que se mostró la capilla ardiente y el cortejo fúnebre. Las imágenes, una realización con tres cámaras que mostraban el plano general de la fila, el detalle de la persona que se ponía de frente al féretro para la despedida y un plano del cadáver, se han mostrado repetidas veces en documentales de todo tipo, sobre todo en La Transición (1995), de Victoria Prego, serie documental que fijó la versión oficial sobre ese periodo político.

La importancia histórica de esas imágenes era tan evidente, que en seguida empezaron a ser parodiadas, como por ejemplo en la película Hic Digitur Dei (Antoni Martí, 1976), película realizada en Súper 8 en el ambiente underground de Barcelona. La película quiere ser una parábola sobre la educación sentimental de una generación de españoles, educados en las radionovelas y en los cuestionarios sentimentales de las revistas. En un momento dado de la película, asistimos a una grotesca dramatización de la capilla ardiente de Franco, en la que militares desdentados, bailarinas con barba y tutú, bebés con botellas de whisky y una parodia del Marqués de Villaverde, se van acercando lentamente al féretro donde agoniza el dictador.

Sin embargo, el cine de la Transición no se mostró tan interesado en interpretar la figura de Franco como en neutralizar a sus seguidores. Muchos de los miedos que atenazaban al país tenían que ver con la amenaza de la extrema derecha, cuya violencia y extorsión llenaba los periódicos. Hasta 1979, la extrema derecha provocó 66 muertos, de los que el cine se hizo eco, como en Siete días de enero (Juan Antonio Bardem, 1979) o Los ojos vendados (Carlos Saura, 1978). La primera película que mostró esta violencia fue Camada negra (Manuel Gutiérrez Aragón, 1977), que se abre sintomáticamente con el atentado a una galería de arte donde están expuestos cuadros y carteles del Equipo Crónica. La película se mueve en un tono metafórico, al contar la historia de una mujer autoritaria que alimenta y adoctrina a un grupo de jóvenes en la violencia y en la ideología de extrema derecha. La tapadera que tienen es la participación en un coro eclesiástico. 
En la última escena, el más pequeño del grupo, un adolescente, se va al monte con su novia, y mientras empiezan a besarse y a desnudarse, él coge una piedra y le destroza la cara a la joven al grito de «España». Tras el asesinato, cava un hoyo, tira el cadáver y planta un árbol, en una escena de clara connotación simbólica. ¿Qué nacerá de ese árbol? ¿La semilla de nuestra juventud es un cadáver?

Otra película, estrenada dos años más tarde, sin embargo es más explícita respecto a su cadáver y al significado de este. Es El diputado (Eloy de la Iglesia, 1979). La película, contada en un largo flashback, nos muestra a Roberto Orbea, militante del Partido Comunista de España en el momento a punto de ser elegido Secretario General del partido. Sin embargo, esa misma noche, un comando terrorista de extrema derecha le ha chantajeado asesinando a su amante. Roberto Orbea es homosexual, lo que le conminaba a una doble clandestinidad, política y sexual. La escena del hallazgo del cadáver (el amante de Roberto Orbea está interpretado por José Luis Alonso, el mismo que interpretaba al adolescente asesino en Camada negra) es bastante explícita:

\section{Jefe Comando: Sorprendido.}

Roberto Orbea: ¿Por qué? ¿Por qué han hecho esto? Yo he venido a su cita antes de que acabase el plazo que me han dado... ¿Piensan matarme a mí también?

Jefe Comando: No. Nos resulta mucho más divertido que un líder de la izquierda tenga que explicar la aparición de un cadáver en su apartamento. En su apartamento secreto. Le deseamos mucha suerte mañana en su congreso. Le elegirán Secretario General, ¿verdad? Enhorabuena.

Sin embargo, el cadáver de Tatín no estaba dirigido a la extrema derecha, sino a la izquierda parlamentaria. Y más concretamente al Partido Comunista de España. Eloy de la Iglesia era, como su personaje, miembro del Partido Comunista y homosexual. Había sentido la homofobia de sus compañeros de partido y se había sentido obligado a adoptar la misma clandestinidad emocional que su personaje. El día del estreno sentó en primera fila a La Pasionaria y a Carrillo, y les puso de frente a sus propias contradicciones, las de un partido que quería reformas políticas sin atender a las libertades individuales.

Pero la película que más lejos llevó la metáfora de España como un país lleno de cadáveres provenía de los márgenes de la industria. Ya desde su propio título Cada ver es... (Ángel García del Val, 1981) anuncia su tema: la extraña relación de un hombre con la muerte. Es un documental que muestra una jornada de trabajo de Juan Espada, encargado del cuidado y mantenimiento de los cadáveres de la Facultad de Medicina de Valencia:

«en el seguimiento del trabajo rutinario del protagonista y en sus comentarios se trasluce la represión emocional, política y sexual que ejerció el franquismo sobre este individuo (convertido en metáfora de la ciudadanía española) al que se acabó abocando a vivir entre cuerpos sin vida» (LÓPEZ CARRASCO y PARÉS, 2017).

En un momento dado, cuenta su experiencia como combatiente del ejército republicano, y cómo vio un campo lleno de cadáveres y salió corriendo atenazado por un miedo infinito. Hasta que, como el protagonista comenta, se acostumbró a los cadáveres. La película muestra, de una forma clara, que todos los españoles de esa época eran cadáveres, que el recuerdo de la Guerra Civil solo puede ser un recuerdo de muerte, recogiendo en cierto modo las reflexiones de Dámaso Alonso en su poema. 
La película no solo es explícita temáticamente sino sobre todo formalmente. Hay decenas de planos detalles de cadáveres, y vemos por ejemplo a Espada serrar un cráneo y partirlo en dos. Vemos cadáveres de ancianos y también de bebés, y entre ellos, un hombre anodino, que trabaja con ellos y los manipula con una total naturalidad, como si pudiese ser habitual trabajar entre cadáveres. Pero para él sí lo es, y según confiesa, a veces habla con ellos y les pide perdón antes de hacerles algo que no les hubiese gustado que les hicieran cuando estaban vivos. Cada ver es... quizá sea la obra más radical de todo el cine de la Transición. Por eso la persecución de la que fue objeto tiene algo de ejemplarizante en las relaciones entre el poder y el cine.

«A esta película, temática y formalmente radical, el Estado le otorgó la categoría S (destinada a las películas de alto contenido erótico), con lo que su circulación se vio mermada. Ante los recursos de los productores, se le acabó negando la posibilidad de estreno comercial debido a su rodaje en $16 \mathrm{~mm}$, lo que la "alejaba" de la calidad necesaria para el circuito comercial. Este subterfugio, donde se entrevé la excusa administrativa para cercenar películas incómodas, anula toda la práctica documental y experimental por la vía burocrática. Hasta ese momento toda la producción documental se realizaba en $16 \mathrm{~mm}$, debido a circunstancias económicas. Como escriben Pena y Cerdán, Cada ver es... se convierte en la "lúgubre metáfora de lo ocurrido con el cine peninsular más inconformista y más radical"» (LÓPEZ CARRASCO y PARÉS, 2017).

A partir de aquí, los cadáveres desaparecieron del cine español, y lo que apareció fueron imágenes de un pasado no beligerante, comedias protagonizadas por personajes de clase alta o académicas adaptaciones literarias que extraían de los libros adaptados solo un telón de fondo sobre el que construir un costumbrismo del pasado. El cine de los años ochenta se intentó forjar a imagen y semejanza del academicismo europeo, olvidando no solo los orígenes populares del cine español, sino las vetas creativas más fuertes de nuestra cultura.

El cine español de los años ochenta se desentendió de la actualidad, y dejó de ser un eco o un altavoz de las preocupaciones que tenía la sociedad. Era un cine aspiracional, que no reflejaba la sociedad que éramos sino la sociedad con la que soñábamos. El cine se convirtió así en la mejor representación de la filosofía socialdemócrata que gobernaba el país: España había dejado atrás la oscuridad y por fin abrazaba la modernidad. Este estado anímico se vio refrendado por el éxito internacional de los Juegos Olímpicos y de la Exposición Universal de Sevilla. El mensaje era claro: España ya era un país como los demás.

Poco a poco fueron apareciendo cadáveres en el cine español, enlazando siempre con esa tradición de los años cincuenta y sesenta donde los cadáveres hacían reír y no pensar. En el año noventa se estrenó Aquí huele a muerto... (¡Pues yo no he sido!) (Álvaro Sáenz de Heredia), protagonizada por el popular dúo cómico Martes y Trece, una parodia de Drácula con muertos vivientes que se creen muertos de verdad y viceversa. La película fue un éxito enorme de público, que se prolongó con su siguiente parodia, esta vez de las películas de atracos, El robobo de la jojoya (Álvaro Sáenz de Heredia, 1991).

Sin embargo, no sería hasta el año 1997 que los cadáveres alcanzaron de nuevo la primera plana. Perdona bonita, pero Lucas me quería a mí era la segunda película de Félix Sabroso y Dunia Ayaso. La trama gira alrededor del hallazgo del cadáver de Lucas, compañero de piso de los tres protagonistas, homosexuales que estaban perdidamente enamorados de él, creyendo 
cada uno de los cuales que su amor era el correspondido. Uno de los tres ha de ser el asesino, pero ¿quién? A partir de aquí se desarrolla una trama basada en clichés que estereotipaban a los homosexuales, convirtiéndolos de forma involuntaria en algo risible. También era, de nuevo, la puesta en escena de una juventud cuyos hábitos de ocio habían cambiado totalmente, y para la que la noche, las discotecas y las drogas se habían convertido en una salida vital.

Lo importante en Perdona bonita... no era la trama sino la estética. La película fue definida en su estreno como «loca», "desmadrada» o "gamberra", adjetivos que habían acompañado también la recepción de las primeras películas de Almodóvar. Pero al contrario de este, no se podía hacer un retrato de un país que estaba cambiando, pues Perdona bonita... tendía hacia una exageración que imposibilitaba cualquier tipo de reflexión. La escena final, en la que los tres amigos se deshacen del cadáver para proseguir con su vida, se nos aparece sin embargo como muy sintomática de esa voluntad de no mirar a los problemas de frente.

Muy poco después, hubo un intento de volver a situar un cadáver en el centro de una trama, a través de la cual mostrarnos las penurias socioeconómicas del país. El director era Javier Maqua y la película Carne de gallina (2002). Ahí se cuenta cómo una familia, cuyo padre acaba de morir, se ve obligada a esconder el cadáver (y ocultar la muerte) para, tras muchos días de zozobra, esperar la llegada de un salvador crédito a nombre del muerto. La acción está localizada en un deprimido pueblo minero de Asturias, donde la reconversión industrial había llenado los bares de parados sin futuro, escenario muy diferente del «España va bien» que el gobierno del Partido Popular vendía como lema. De esta forma Maqua no solo entroncaba con la tradición de los Ferreri, Berlanga y Azcona, sino que hacía una película claramente política en un tiempo en el que el cine social español parecía un remedo malo y feo del cine de Ken Loach, sin su fuerza ni su fe.

La iniciativa de Maqua de recuperar el cadáver como algo subversivo, que a fuer de hacernos reír delataba nuestras propias contradicciones, no tuvo sin embargo continuidad. Los cadáveres fueron recuperados para la comedia, pero en la vertiente festiva y frívola de Alfonso Paso, eso sí, con una puesta al día estética. De repente, los cadáveres del cine español eran cadáveres modernos. No en vano los tres directores a los que automáticamente se les adjudicaba la etiqueta de modernos, Pedro Almodóvar y el dúo Félix Sabroso/Dunia Ayaso, siguieron explorando la comedia con cadáver. Almodóvar con Volver (2006), que pretendía ser una vuelta a ¿Qué he hecho yo para merecer esto? (1984), en la que el personaje de Penélope Cruz guarda el cuerpo de su marido en un congelador del restaurante de un vecino, del que no pueden deshacerse por la presencia de un equipo de rodaje, que almuerza y cena en la casa. Por su parte, el dúo Sabroso/Ayaso hicieron Descongélate! (2003), en la que un director de cine fallece en el salón del que va a ser el protagonista de su película, que decide esconder el cadáver hasta que firme el contrato. Pero ni Volver consiguió convertir el costumbrismo en retrato de la periferia, ni el dúo de cineastas consiguieron hacer reflexionar sobre la precariedad laboral.

Por ello, no es de extrañar que el cineasta actual que más se emparenta con los citados, Paco León, retomase la comedia con cadáver en Carmina y amén (2014). Esta película retoma, de forma inconsciente, el argumento de Carne de gallina: una madre y su hija deberán guardar el cadáver del padre durante todo un fin de semana para poder cobrar la paga extraordinaria del fallecido. Como Maqua, León intenta naturalizar el uso de un acento 
no normativo, en este caso el andaluz. Sin embargo, aquí no hay una lectura política, sino la actualización del sainete costumbrista, con una pizca de reflexión social biempensante.

Como hemos visto, para la cultura española, mirar un cadáver de frente es un acto de subversión, porque lo que hay que hacer es velarlos y rezarlos, pero no mirarlos. De ahí la falta en España de cadáveres carismáticos, de cadáveres conocidos, de culto a un cadáver. Por ejemplo, José Antonio Primo de Rivera, el muerto más adorado y conocido del franquismo, del que sin embargo nunca se vio su cadáver. Lo que sí se vio el espectáculo de su entierro, en un guion minuciosamente ejecutado. Sus restos fueron exhumados de la cárcel de Alicante y llevados a hombros, desde esa ciudad a El Escorial, por grupos de falangistas, secundados por muchos otros que portaban antorchas. José Antonio es una prueba de que no nos atrevemos a mirar al cadáver, pero sí nos gusta acudir al funeral. En ese acto de apartar la mirada, caben los chistes pero no la reflexión.

Quizá esto se deba en último término a la conversación nunca terminada en España sobre qué hacer con los cadáveres de la Guerra Civil y la inmediata posguerra que siguen en las cunetas. A base de no querer abrir heridas, las heridas no se cierran nunca. En cierto modo, hablar de un cadáver en España es por comparación hablar de ese millón de cadáveres (en exitosa expresión de José María Gironella) que dejó la Guerra Civil y de los que solo la mitad han sido enterrados dignamente. Esos cadáveres son una presencia fantasmagórica y terrorífica, y como parece que se cree, ante el miedo, el mejor antídoto es la risa.

\section{Referencias bibliográficas}

ALONSO, Dámaso (1990). Hijos de la ira. Edición de Fanny Rubio. Madrid: Espasa-Calpe.

LÓPEZ CARRASCO, Luis y PARÉS, Luis E. (2017). Confort y conflicto (y II). De cómo el cine español se desconectó de la realidad en los años ochenta. CTXT-Revista Contexto, 135, 22 de septiembre de 2017. Recuperado de: https://ctxt.es/es/20170920/Culturas/15119/cines-a\%C3\%B1os-ochentatransicion-franquismo-ley-miro.htm [acceso: 17 de julio de 2019]

MINISTERIO DE JUSTICIA (1943). La dominación roja en España: avance de la información instruída por el Ministerio Público: causa general. Madrid: Ministerio de Justicia. 